\title{
PROTOTIPE INTEROPERABILITAS LEARNING TECHNOLOGY SYSTEM ARCHITECTURE (LTSA) PADA KONSEP M-LEARNING
}

\author{
Aan Erlansari ${ }^{1}$ \\ ${ }^{1}$ Program Studi Teknik Infomatika, Fakultas Teknik, Universitas Bengkulu. \\ Jl. WR. Supratman Kandang Limun Bengkulu 38371A INDONESIA \\ (telp: 0736-341022; fax: 0736-341022) \\ ${ }^{1}$ sir.erlan@yahoo.com
}

\begin{abstract}
Abstrak: Standar pembelajaran e-learning yang telah beralih ke sistem yang modern menjadi pilihan berbagai pusat pembelajaran. Standar teknologi pembelajaran diperlukan agar sistem pembelajaran yang dibangun mempunyai kemampuan dalam Interoperability, Re-usability, Manageability, Accessibility dan Durability. LTSA merupakan salah satu standar yang dikeluarkan oleh IEEE, menetapkan standar arsitektur tingkat tinggi untuk mendukung sistem pembelajaran, pendidikan dan pelatihan. Pada paper ini dibahas interoperabilitas e-learning menggunakan standar LTSA dan penerapannya pada aplikasi open source Moodle. Konsep LTSA sebagai arsitektur tingkat tinggi juga dapat diintegrasikan ke bentuk standar lainnya
\end{abstract}

Kata Kunci: e-learning, LTSA, IEEE, open source, moodle

Abstract: E-learning standards that have switched to a modern system of choice of various learning centers. Learning technology standards needed to be a learning system that is built has the ability to Interoperability, re-usability, manageability, Accessibility and Durability. LTSA is one of the standards issued by IEEE, set the standard high level architecture to support learning systems, education and training. In this paper discussed the interoperability of e-learning using LTSA standard and its application to the Moodle open source applications. LTSA concept as the high level architecture can also be integrated into other standard forms

Keywords: e-learning, LTSA, IEEE, open source, Moodle

\section{PENDAHULUAN}

Perkembangan teknologi informasi dan komunikasi (Information and Communication Technology, ICT) serta internet, telah menciptakan berbagai produk layanan. Sekarang sudah tidak asing lagi dengan istilah-istilah baru yang berawalan dengan "e- " yang artinya elektronik. electronic commerce atau e-commerce, e- Busines, e-Book, eGovernment dan sejumlah istilah lainnya.

Penerapan ICT dalam dunia pendidikan memunculkan beberapa istilah yaitu e-Learning, $e$ Training, Online Learning, Tele Learning, Distance Education, Distance Learning dan sebagainya. Semua itu merupakan produk yang memanfaatkan ICT untuk mendapatkan pelayanan yang efektif dan efisien.

Standar teknologi pembelajaran diperlukan agar sistem pembelajaran yang dibangun mempunyai kemampuan dalam Interoperability, Re-usability, Manageability, Accessibility dan Durability. Menurut IEEE LTSC (IEEE Learning Technology Standards Committee), standar teknologi pembelajaran yang dikembangkan meliputi Architecture and Reference Model (WG1 LTSA), Digital Rights Expression Language (WG4 DREL), Computer Managed Instruction 
Jurnal Pseudocode, Volume III Nomor 2, September 2016, ISSN 2355-5920

(WG11 CMI), Learning Object Metadata (WG12

LOM) dan Competency Definitions (WG20 RCD).

Metode penyampaian e-learning memainkan peranan penting dalam penyediaan layanan $e$ learning, banyak organisasi dan individu masih menghadapi hambatan dan tantangan yang berkaitan dengan layanan ini. Termasuk didalamnya program pendidikan yang tidak diperbaharui, kesulitan mengakses materi pendidikan yang berkualitas, teknologi yang tidak memadai atau sudah usang yang masih digunakan dalam pemberian layanan pembelajaran. Dari hambatan-hambatan yang ada tercipta peluang untuk meningkakan efisiensi dan efektivitas sistem penyampaian pembelajaran via e-learning melalui berbagai peningkatan sumber daya dan penyebaran konten pembelajaran yang sesuai dengan kebutuhan sebenarnya dari kelompok profesional masyarakat. Sehingga tercipta beberapa interoperabilitas untuk e-learning, diantaranya [1]:

1. AICC (The Aviation Industry CBT Committee)

2. IMS (The Instructional Management System)

3. ADL SCORM (Advanced Distance Learning Shareable Courseware Object Reference Model)

4. IEEE LTSA (The Institute of Electrical and Electronics Engineers Learning Technology Systems Architecture)

Standar interoperabilitas e-learning yang digunakan pada makalah ini adalah standar IEEE LTSA (The Institute of Electrical and Electronics Engineers Learning Technology Systems Architecture).

\section{LEARNING TECHNOLOGY SYSTEMS}

\section{ARCHITECTURE (LTSA)}

Arsitektur teknologi sistem pembelajaran sampai saat ini yang banyak digunakan adalah LearningTechnology Systems Architecture (LTSA). LTSA dipandang sebagai sistem yang relatif lengkap untuk pengembangan teknologi pembelajaran. Hal ini sejalan dengan yang dipaparkan oleh Kridanto Surendro [2] bahwa LTSA merupakan hasil penelitian yang dilakukan oleh divisi edutool dari Farance Incorporation yang dikembangkan berdasarkan IEEE 1484.

LTSA adalah arsitektur yang menggambarkan rancangan sistem level tinggi beserta komponenkomponennya. LTSA mencakup sistem yang banyak dikembangkan dan dikenal sebagai learning technology, education and training technology, computer-based training, computer assisted instruction, intelligent tutoring, metadata, dan sebagainya. Arsitektur ini bersifat netral terhadap aspek pedagogi, isi, budaya, dan platform dari suatu sistem pengajaran. Lebih lanjut dijelaskan bahwa LTSA terdiri dari lima lapis arsitektur yang dapat dilihat pada gambar 1. Setiap layer menggambarkan sebuah sistem pada level yang berbeda. Layer yang lebih tinggi memiliki prioritas yang lebih besar dan berpengaruh dalam analisis dan perancangan sistem. Dengan kata lain, layer yang lebih tinggi merupakan abstraksi dari layer yang di bawahnya, sedangkan layer yang lebih rendah merupakan implementasi dari layer yang di atasnya [3]. 


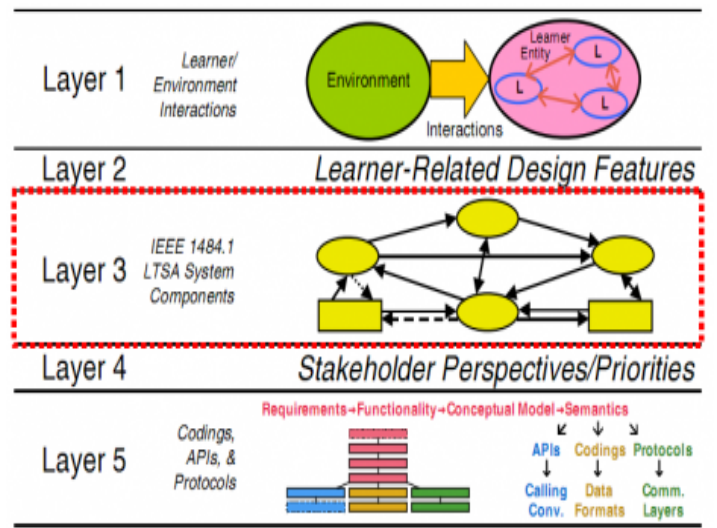

Gambar 1. Arsitektur LTSA

Adapun layer-layer di atas dapat dijelaskan sebagai berikut :

\section{Layer 1: Learner and Environment Interactions,} lapisan ini berfokus pada akuisisi, transfer, pertukaran, formulasi, dan penemuan dari siswa terhadap pengetahuan dan/atau informasi melalui interaksi dengan lingkungannya.

Layer 2: Learner-Related Design Features, lapisan ini berfokus pada pengaruh atau efek yang dimiliki siswa pada perancangan dari sistem pembelajaran.

Layer 3: System Components, lapisan ini mendeskripsikan komponen dasar arsitektur yang diidentifikasi pada lapis ke-2.

Layer 4: Implementation Perspectives and

Priorities, lapisan ini mendeskripsikan sistem pembelajaran dari berbagai perspektif dengan mengacu pada lapis ke-3. LTSA telah memformulasikan lebih dari 120 stakeholder perspective. Setiap stakeholder memiliki perspektif yang berbeda terhadap sistem pembelajaran.

Layer 5: Operational Components and Interoperability, lapisan ini mendeskripsikan komponen dan antarmuka yang bersifat generik dari arsitektur pembelajaran berbasis teknologi informasi seperti yang diidentifikasi pada lapis ke4.

\section{ENTERPRISE PLATFORM}

\section{A. Transaction Process}

Poin utama dalam standar LTSA adalah penyampaian informasi kepada peserta didik melalui multimedia (informasi visual dan audio). Lapisan ketiga dalam arsitektur LTSA mengatur transaksi dan hubungan dalam aplikasi e-learning, yang terdiri dari 3 (tiga) komponen utama :

- Proses : Learner, evaluation, System Coach, process

- Flows: Behavior, Assessment, Performance, Query IndexContent Index, Locator Index, Learning Content, Multimedia, Learning Style.

- Stores: Records Database, Knowledge Library

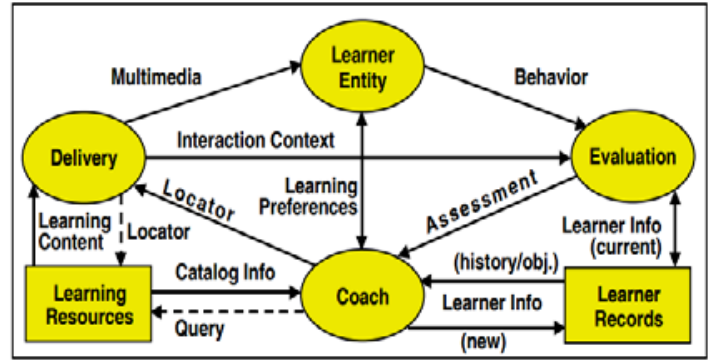

Gambar 2. LTSA lapisan 3

Keseluruhan aliran dalam lapisan ini memiliki bentuk sebagai berikut :

a. Strategi pembelajaran dapat dinegosiasikan antara peserta didik dan stakeholder

b. Siswa diamati dan dievaluasi

c. Evaluasi menghasilkan nilai atau informasi kinerja

d. Informasi kinerja disimpan dalam basis data sejarah siswa

e. Pendidik meninjau hasil kinerja siswa

f. Pendidik menyiapkan konten pembelajaran yang tepat

g. Pendidik mengekstraksi rencana pembelajaran 
h. Mengubah konten pembelajaran untuk presentasi multimedia interaktif

Sistem pembelajaran yang baik biasanya menyediakan fasilitas yang dapat menginteraksikan antara sistem, tutor dan siswa, seperti fasilitas email antar tutor dan muridnya yang terdaftar dalam satu materi yang sama, begitu juga akses terhadap staf administrasi yang menangani sistem.

\section{B. Object Transition}

Lapisan I pada LTSA merupakan lapisan tertinggi yang terdiri dari 2 (dua) proses dan 1 (satu) aliran data. Salah satu prosesnya yaitu entitas dari siswa mewakili beberapa sub-sistem. Entitas dari siswa (learner entity) merupakan sebuah konseptual abstraksi dari human learner. Entitas dari siswa bisa mewakili seorang pelajar tunggal, sekelompok siswa dan sekelompok siswa yang belajar dalam peran yang berbeda. Entitas siswa mendukung untuk pertukaran inforamsi dari dan ke berbagai proses lainnya dalam arsitektur LTSA, seperti dijelaskan pada gambar 3.

\section{Application Framework}

Berikut ini adalah langkah utama dalam pengembangan standar interoperabilitas dalam Teknologi Informasi yang diterapkan pada standar LTSA :

a. Requirement, memungkinkan untuk membuat kerangka standar atau spesifikasi penggunaan.

b. Functionality, memberikan batasan tertentu terhadap sistem yang meminimalkan terobosan fitur, untuk mencegah terhadap bahaya yang akan timbul dikemudian hari.

c. Conceptual Mode, menjabarkan implementasi virtual yang memodelkan teori operasi. Untuk tahap pemeliharaan fase siklus hidup sistem. model konseptual dapat digunakan untuk menyelesaikan ambiguitas dalam semantik yang tak terdugaatau diabaikan untuk pembangunan sistem.

d. Semantic, menjelaskan makna yang jelas dari interoperabilitas.

e. Binding, menggambarkan pemetaan untuk pengkodean tertentu, format file, API, perintah, protokol, set transaksi dan lain sebagainya.

f. Encoding, menggambarkan bit-bit representasi dan memungkinkan mereka untuk dipisahkan dari struktur informasi.

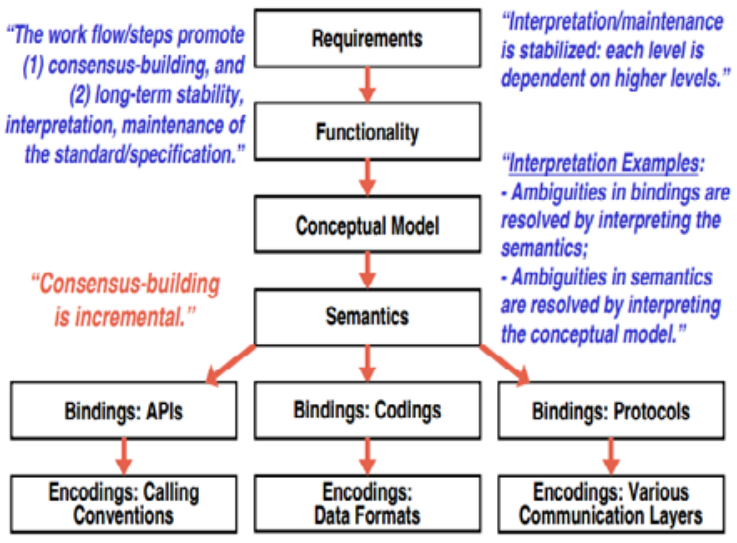

Gambar 3 Langkah Utama Pengembangan Standar Interoperabilitas LTSA

Dengan memisahkan standar atau spesifikasi pengembangan aplikasi dalam beberapa langkah, permasalahan yang memiliki resiko tinggi dapat diketahui dan diatasi lebih awal, sedangkan untuk permasalahan yang beresiko rendah dapat ditunda.

\section{IV.LTSA ENTERPRISE INTEGRATED}

Sistem pembelajaran LTSA terintegrasi dengan beberapa komponen yang mendukung pengembangan e-learning :

a. LCDS (Learning Component Development System), sistem komponen yang 
mengembangkan fitur grafik, konten multimedia, dokumen web, dalam versi HTML, DHTML, XML dan Java.

b. LCMS (Learning Component Management System), komponen manajemen sistem yang digunakan untuk membuat objek pembelajaran dapat digunakan kembali yang dapat diakses di repositori objek.

c. LDS (Learning Delivery System), atau bisa disebut sebagai kelas virtual, digunakan untuk penyampaian proses e-learning langsung melalui jaringan. Sistem ini mereplikasi sistem tradisional untuk membantu siswa meningkatkan kemampuan berinteraksi, berkolaborasi dan belajar.

Secara garis besar integrasi LTSA dengan komponen-komponen pengembangan e-learning terkait diatas dapat diilustrasikan seperti gambar berikut :

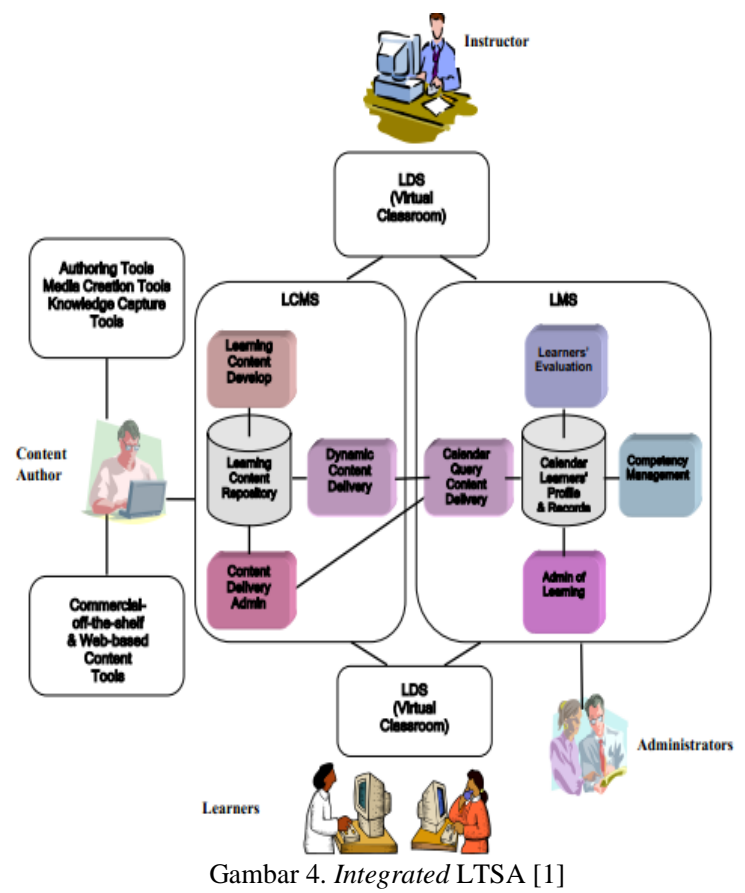

LTSA sebagai sebuah standar e-learning berhubungan dengan keempat komponen pengembangan e-learning diatas untuk mempertahankan para peserta didik mendapatkan preferensi penetapan kursus yang sesuai dengan pilihan yang tersedia, memonitor kemajuan kursus, mengevaluasi kemajuan peserta didik selama kursus dilangsungkan dan beradaptasi dengan bahan yang diberikan.

Untuk mendukung kinerja integrasi LTSA, sebuah web browser dijembatani sistem bus dari internet ke dalam “web-bus”. Web-bus internet ini mewakili semua browser (klien) dan web server yang dapat berkomunikasi satu dan lainnya.

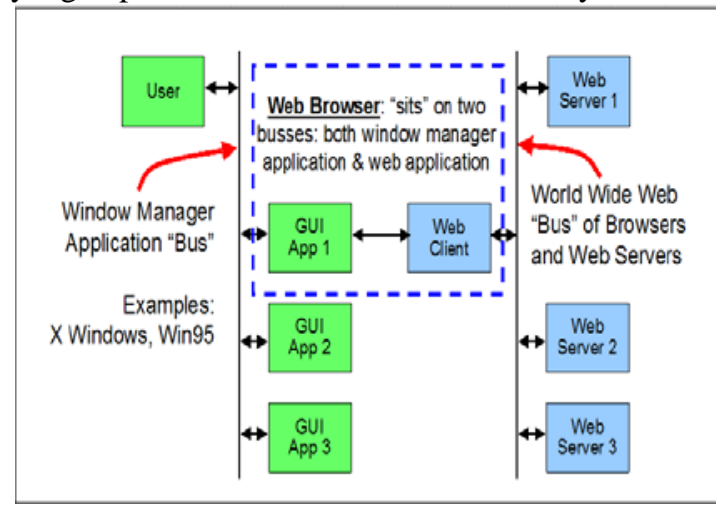

Gambar 5. Enterprise Model menggunakan notasi Bus

Setiap bagian bus menggunakan protokol yang sama untuk meminta atau merespon transaksi yang terjadi. Model bus digunakan untuk mewakili dan melaksanakan kontrol aliran mekanisme umum, seperti menjalankan dan menghentikan transaksi/alur informasi.

\section{INTEGRASI LTSA DENGAN STANDAR E- LEARNING LAINNYA}

Untuk memastikan interoperabilitas distribusi seluruh sistem dan jaminan dari reusability instructional content, beberapa standarisasi telah diluncurkan [4]. Pada bulan November 1997 pemerintah Amerika Serikat melalui Department of Defense (DoD) dan White House Office of Science and Technology Policy (OSTP) membentuk suatu badan khusus Advance Distributed Learning (ADL). ADL dibentuk dari sekumpulan individu dan institusi yang secara 
kolaboratif bekerja bersama-sama dengan memanfaatkan teknologi informasi untuk dapat memodernisasi struktur belajar yang ada saat ini. Hasil kolaborasi yang membentuk ADL ini secara bersama-sama mengembangkan standar, tools dan learning content untuk lingkungan belajar masa depan.

Sebagai arsitektur e-learning tingkat tinggi, LTSA mampu berkolaborasi dan berinteraksi dengan standar e-learning lainnya. Pada paper ini kami menganalis interaksi yang dapat dibangun antara LTSA dan standar SCORM.

SCORM (Shareble Content Object Reference Model) merupakan standarisasi pendistribusian konten e-learning yang dikeluarkan oleh ADL (Advanced Distributed Learning). Standarisasi ini memungkinkan pertukaran objek pembelajaran antara LMS yang satu dengan yang lainnya, sehingga konten pembelajaran tersebut dapat digunakan terus menerus (reusability) dengan memperbaharui isi tanpa membuat dari awal lagi [5].

Manfaat utama dari SCORM adalah interoperabilitas. Jika anda menghasilkan konten $e$ learning, selalu satu (atau lebih mungkin banyak) dari klien anda akan meminta anda untuk mengintegrasikan konten yang menjadi LMS. Demikian pula, jika anda menghasilkan sebuah LMS dapat dipastikan bahwa klien anda akan ingin mengimpor konten dari sejumlah sumber yang berbeda ke dalam LMS. SCORM memungkinkan integrasi ini terjadi mulus dan sederhana. Tanpa SCORM, mengintegrasikan dengan vendor lain adalah proses yang memakan waktu dan mahal. SCORM akan membuat organisasi anda lebih efisien dan mengurangi beban dukungan anda. a. Shareble Content Object (SCO)

Sharable Content Object (SCO) mewakili sekumpulan dari asset dimana didalamnya terdapat sebuah asset yang dapat di-launch pertama kali dengan memanfaatkan SCORM Run Time Environtment untuk melakukan komunikasi dengan Learning Management System (LMS). SCO adalah bagian terkecil dari sebuah materi pembelajaran yang dapat di-tracking oleh LMS dengan SCORM Run Time Environtment.

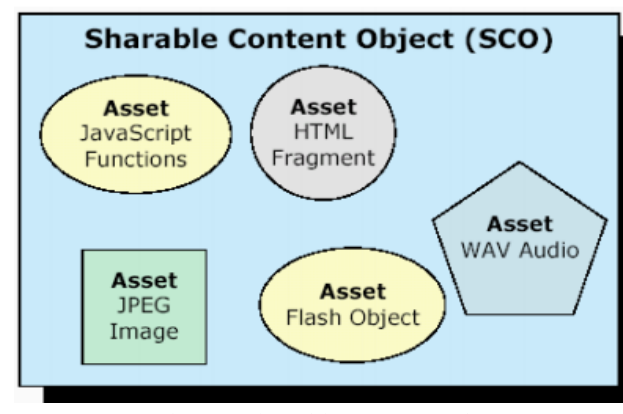

Gambar 6. Shareble Content Object [6]

b. Interoperabilitas SCORM

Letak interoperabilitas SCORM dapat dilihat dari arsitekturnya yang mengimplementasikan API dan Runtime Environment sebagai service. Pengguna dapat berinteraksi dengan SCORM menggunakan layanan tersebut. Kerangka utama dari SCORM :

- Metadata: satu set metadata yang menjelaskan konten pembelajaran sehingga mudah untuk dicari, diidentifikasi dan diakses

- Paket konten: definisi paket untuk penyampaian dan pertukaran struktur konten (objek pembelajaran dan kursus) diantara standar LMS dan LCMS yang berbeda

- API: layanan komunikasi antar muka yang mengkomunikasikan sumber daya dengan sistem eksternal. 
Kelemahan dan kelebihan LTSA dan SCORM.

Standar LTSA dan SCORM yang diterapkan pada e-learning masing memiliki kelemahan dan kelebihan yang dapat dideskripsikan sebagai berikut :

a. Kekurangan

- SCORM tidak dapat melacak siapa saja yang telah membaca modul yang ada pada $e$ learning

- SCORM menggunakan tampilan yang sederhana

- LTSA tidak menjelaskan fungsi reusability secara jelas

b. Kelebihan

- LTSA dan Scorm diterapkan pada aplikasi yang berbasis open source

- Menerapkan interoperabilitas sehingga mampu diakses dimanapun juga

\section{IMPLEMENTASI LTSA DAN M-LEARNING}

M-learning berhubungan dengan kemampuan mobilitas pengguna dan perangkatnya, dalam artian, seluruh pengguna harus mampu terlibat dalam kegiatan m-learning (proses unggah dan unduh bahan ajar), serta perangkat mampu mengakomodir pengguna untuk dapat mengakses m-learning yang dirancang.

Sistem tersebut dirancang dengan tujuan untuk memenuhi kebutuhan fungsi sebagai mobile adaptor. Fungsi-fungsi tersebut adalah Context discovery, mobile content management, dan presentation management. Dasar m-learning yang akan diterapkan berbasis client server, dengan demikian seluruh konten pembelajaran diproses pada bagian server dan nantinya akan dapat diakses oleh seluruh client berbasis mobile. Berdasarkan gambar 6, konteks mobile learning diutamakan untuk dapat menjadi sebuah sistem yang berbagi pakai kepada seluruh pengguna tanpa melihat apakah sistem dikonsep dengan menggunakan bahasa pemograman JAVA, PHP MYSQL , HTML dan lainnya.

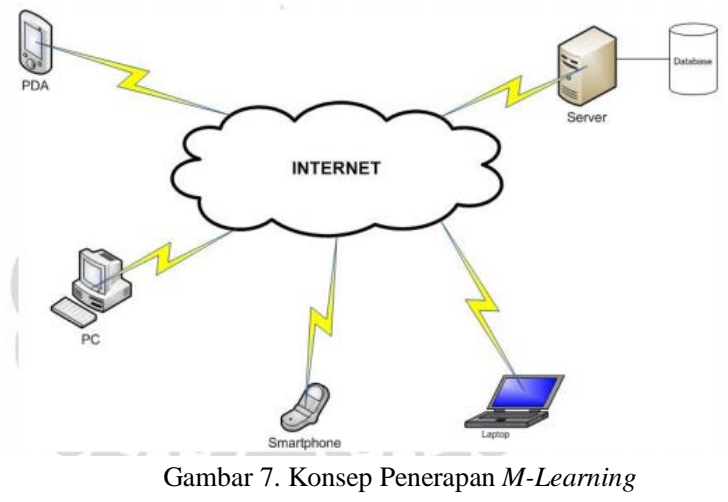

Dari segi arsitektur m-learning pada gambar 7, server bertindak sebagai pengelola seluruh data pemebelajaran dan aktivitas lainnya dalam $m$ learning. Server tersebut terhubung dengan sebuah personal desktop yang akan digunakan untuk mengelola dan mengembangkan sistem serta digunakan oleh admin dan pemateri untuk dapat mengelola bahan ajar. Proses berbasis server, dapat dilakukan dengan menyediakan berbagai versi penggunaan untuk client-nya. Sttruktur global konten disesuaikan sehingga pengguna tidak memiliki keterbatasan dari segi perangkat lunak tambahan untuk dapat mengakses server $e$ learning. Pengguna yang berbasis mobile, mempunyai hubungan untuk dapat mengakses seluruh fasilitas yang telah dikembangkan dalam sistem dan digunakan dalam sistem pembelajaran.

Dalam beberapa hal, konsep m-learning didahului oleh pengembangan pembelajaran berbasis e-learning. Komponen m-learning akan disisipkan ke dalam lapisan software product yang berisi e-learning SPL dan m-learning SPL. oleh karena itu, e-learning dan m-learning memiliki keterkaitan khusus. Perbedaan yang mendasar hanyalah dari segi aksesibilitas sistem, e-learning 
atau dapat disebut juga dengan distance learning dapat diakses cukup dengan menggunakan komputer yang terhubung dengan jaringan ke server, sedangkan m-learning mengharuskan seorang pengguna memiliki perangkat pendukung seperti smartphone. Sehingga terdapat beberapa keterbatasan yang dimiliki oleh m-learning:

a. Karakteristik perangkat yang digunakan, dalam hal ini, perangkat pendukung $m$ learning harus memiliki kemampuan menjalankan aplikasi yang dirancang sesuai dengan sistem operasi yang dijalankan, atau dengan kemungkinan lain, perangkat harus mampu menjalankan aplikasi browser yang didukung oleh server sebagai penyedia layanan.

b. Konektivitas merupakan syarat utama untuk dapat menjalankan sistem m-learning, kebutuhan akan sejumlah bandwith tergantung oleh berapa besar kapasitas yang disediakan oleh sistem. Sebagai contoh, untuk penyediaan konten yang bersifat audio atau video, jumlah bandwith yang dibutuhkan akan lebih besar jika dibandingkan dengan kebutuhan terhadap konten yang hanya menyajikan teks.

Arsitektur LMS yang digunakan pada makalah ini menggunakan konsep UML dengan use case sebagai dasarr aktivitas pengguna, sequence diagram yang berisi aktivitas sistem terhadap pengguna dan diagram aktivitas.

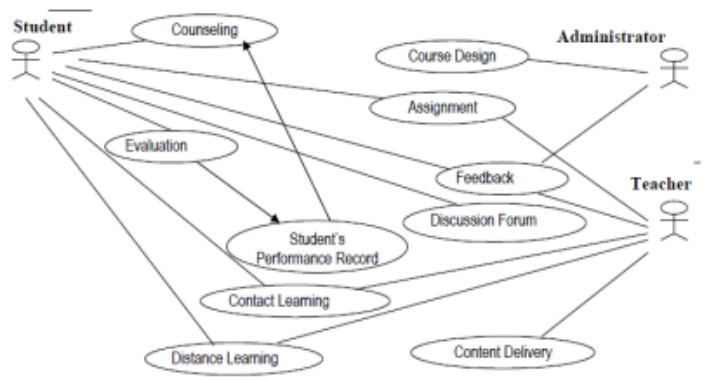

Gambar 8. Use case LMS [6]
Aktor yang terlibat pada gambar 8, adalah student, administrator dan teacher. Setiap aktor memiliki aktivitas tertentu dan akan saling mendukung. Student performance record disimpan dan akan digunakan untuk evaluasi terhadap pengambilan pelajaran lainnya. Forum diskusi merupakan wadah bagi stakeholders untuk dapat mengubah autoritasnya dan aturan pada sistem.

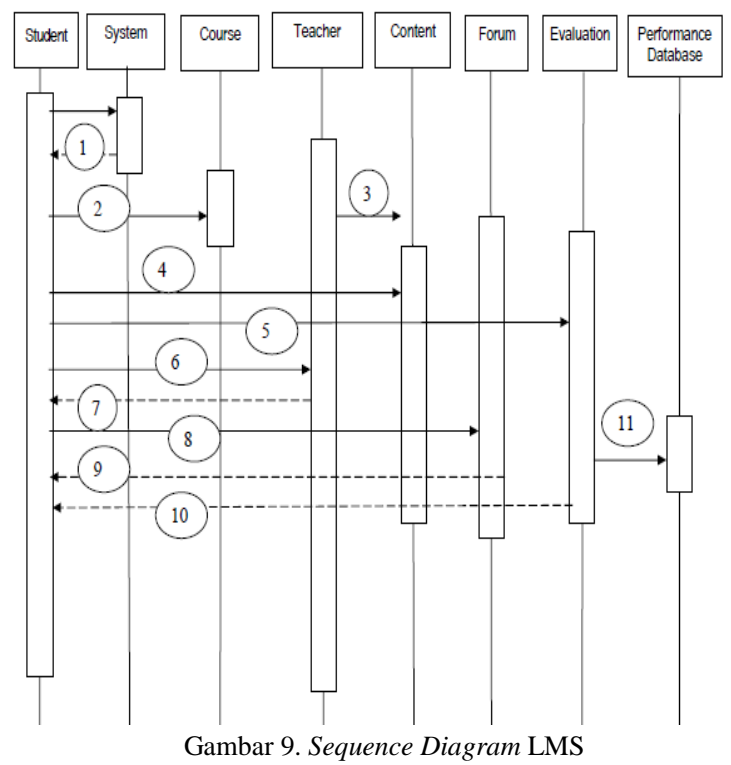

Pada sequence diagram, hubungan antara student dan teacher menjelaskan bahwa student dapat berinteraksi langsung dengan teacher dalam hal sistem pembelajaran secara keseluruhan. Student juga memiliki akses terhadap system, course, content, forum, evaluation dan performance database.

Diagram aktivitas pada gambar 10, menjelaskan skema pembelajaran yang diberikan oleh LMS yang diawali dengan tahapan counseling yang merupakan tahapan awal sebelum memulai pendaftaran terhadap sebuah kursus. Sistem evaluasi diberikan dalam dua tahapan, tahapan online dan dan bisa juga menggunakan sistem offline. Proses activity diagram diakhiri oleh tahapan record performance yang akan 
mengevaluasi seluruh aktivitas student selama sistem pembelajaran.

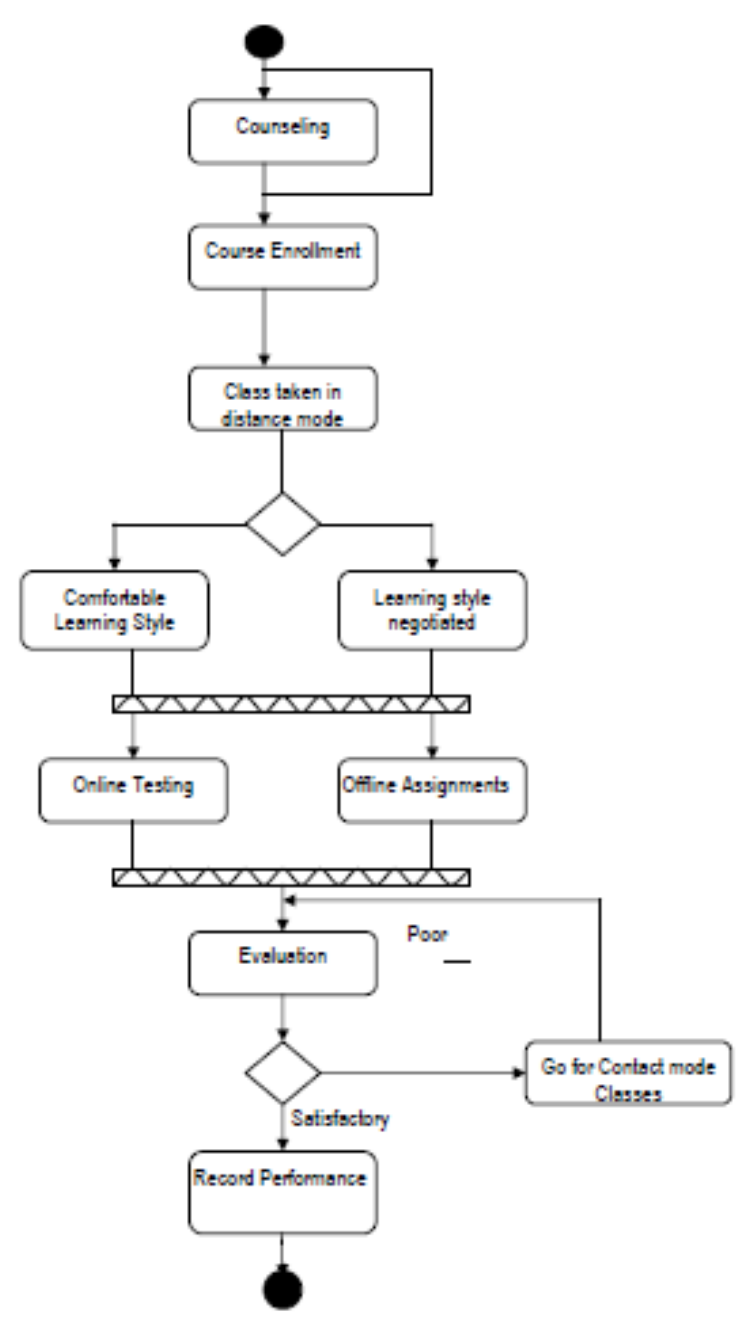

Gambar 10. Activity Diagram LMS

Dalam implementasi LTSA, beberapa bantuan telah dikembangkan oleh pengembang sistem pembelajaran berbasis paket dalam bentuk Learning Management System (LMS), LMS mampu mengakomodir fungsi-fungsi dan komponen yang sudah dispesifikasikan olehnya. Beberapa LMS dapat diadopsi menggunakan konsep LTSA, sehingga implementasi LTSA akan menjamin interoperabilitas dan portabilitas dari sistem yang menggunakannya.
Berikut adalah contoh fitur beberapa LMS dari komponen LTSA :
a. Angel
$\rightarrow(1)$
b. WebCT
$\rightarrow(2)$
c. Blackboard Academic Suite $\rightarrow(3)$
d. eCollege $\mathrm{AU}+$
$\rightarrow(4)$
e. KEWL
$\rightarrow(5)$
f. Moodle
g. Sakai
$\rightarrow(7)$
h. ATutor

Salah satu contoh LMS yang paling umum digunakan adalah Moodle, LMS ini menyediakan sumber daya online untuk memfasilitasi manajemen dan akses terhadap konten dari sistem e-learning. Moodle telah banyak diadopsi oleh institusi pendidikan dan non pendidikan karena strukturnya menekankan untuk dapat mencapai tujuan dengan cara-cara yang objektif dari pembelajaran berbasis online yang memanfaatkan sistem ini.

Proses perancangan m-learning yang berbasis kepada LMS khususnya moodle. Pada tabel dibawah ini akan dideskripsikan perbandingan LMS yang telah berkembang dan yang mendukung sistem LTSA.

a. Learner Tools

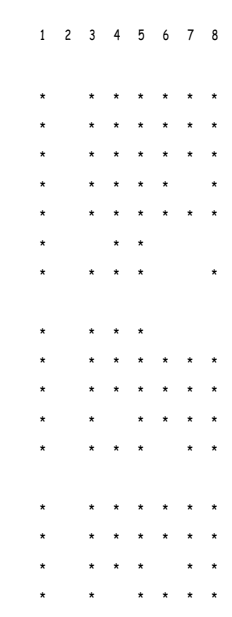

Gambar 11. Learner Tools 


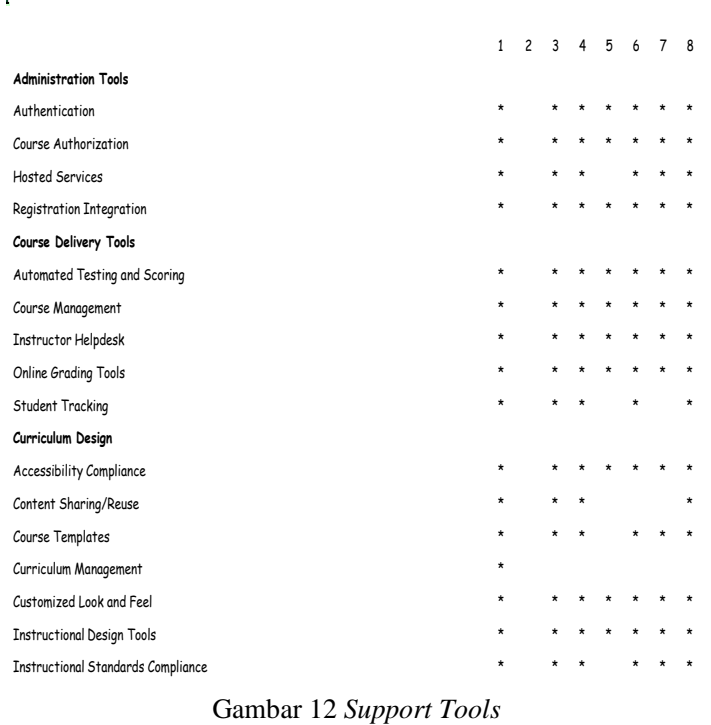

c. Technical Specification

\begin{tabular}{|c|c|c|c|c|c|}
\hline \multicolumn{6}{|l|}{ Hardware/Software } \\
\hline Client Browser Required & * & * * & * & * & * * \\
\hline Database Requirements & * & * & * & * & * * \\
\hline Server Software & * & * & * & * & * * \\
\hline Unix Server & & * & & $\star$ & * * \\
\hline Windows Server & * & & * & * & * * \\
\hline \multicolumn{6}{|l|}{ Pricing/Licensing } \\
\hline Company Profile & * & * * & * & * & * * \\
\hline$\underline{\text { Costs }}$ & * & * * & * & * & \\
\hline Open Source & & & * & * & * \\
\hline Optional Extras & * & * * & * & * & * \\
\hline Software Version & * & * * & * & & \\
\hline
\end{tabular}

Gambar 13 Technical Specification

Masing-masing LMS seperti dijelaskan pada gambar 11, 12 dan 13 memiliki fitur-fitur tertentu. Tidak semua fitur dimiliki oleh seluruh LMS.
Makalah ini menyajikan prototipe perancangan m-learning dengan menggunakan konsep LTSA yang telah diadopsi oleh beberapa LMS yang banyak berkembang. Salah satu contoh LMS yang digunakan pada perancangan sistem ini adalah Moodle. Moodle dianggap sebagai LMS yang mampu memberikan fitur yang benyak mendukung sistem pembelajaran dan moodle dapat diterapkan untuk menjadi sistem yang berbasis mobile. Terdapat tiga (3) aktor utama yang digunakan dalam moodle, student, teacher dan administration, kesemua aktor memiliki fungsi dan aktivitas masing masing. Beberapa fungsi dari use case dijelaskan dapat mendukung aktivitas lanjutan yang akan dilalui oleh seorang student.

\section{REFERENCES}

[1] Eugene Igras, E-Learning Standars And Technology, IRIS SYSTEM Inc, 2007.

[2] Suhendro Krisdanto, Pengembangan Learning Content Management System yang Mendukung Peningkatan Efektifitas Proses Belajar Jarak Jauh, Departemen Teknik Informatika, Institut Teknologi Bandung, 2005

[3] Frank Farance, Joshua Tonkel,Draft Standard for Learning Technology-Learning Technology Systems Architecture (LTSA), New York, 2001

[4] Cassela, G., Costagliola, G., Ferrucci, F., Polese, G. Scanniello, G.. A SCORM Thin Client Architecture for E-Learning Systems Based on Web Services. International Journal of Distance,Education Technologies.

[5] Bohl, O., Schellhase, J., Sengler, R., Winan, U. The Sharable Content Object Reference Model (SCORM) - A Critical Review. Proceedings of the International Conference on Computers in Education. IEEE, 2002

[6] S. Sengupta, S. Pal, N. Banerjee, A comparison algorithm to check LTSA Layer 1 and SCORM compliance in eLearning sites, JOURNAL OF COMPUTING, VOLUME 2, ISSUE 9, 2010 